\title{
Threats, Challenges, and Opportunities for Open Universities and Massive Online Open Courses in the Digital Revolution
}

\author{
https://doi.org/10.3991/ijet.v15i12.13435 \\ Maria Nascimento Cunha \\ Universidade de Aveiro, Aveiro, Portugal \\ Tinashe Chuchu $(\bowtie)$ \\ University of Pretoria, Pretoria, South Africa \\ tinashe.chuchulup.ac.za \\ Eugine Tafadzwa Maziriri \\ University of the Free State, Bloemfontein, South Africa
}

\begin{abstract}
In a world of sharp transformation driven by digital technologies, education is facing a paradigm shift that exposes vulnerabilities and threats of Open Education models in the face of the trend of commodification. This article seeks to offer useful insights into the threats, challenges, and opportunities for open universities and massive online open courses in the digital revolution. The methodology followed a systematic content review of literature. With the advent of the internet, we have verified a profound transformation in the way we communicate and produce within the academics. The digital revolution favored the freedom of access to information. The digital revolution poses challenges but also opens up unprecedented opportunities for democratization and accessibility. The transformation process of open universities has to maintain the referential of the profound incorporation of pedagogical and technological innovation based on research and seek new strategies of organization and definition of quality, to guarantee its relevance and leadership in the pursuit of the massification of higher education.
\end{abstract}

Keywords-Open universities, pedagogy, technology, the digital revolution, MOOCs

\section{Introduction}

Massive Online Open Courses (MOOCs) have emerged as a new educational tool in the higher education sector, due massiveness and open source information [1]. Open universities are generally government-run institutions [2]. According to [2], open universities are highly politicised institutions that emerged due to the incapacity of the higher education sector to meet the challenge of modernity. Higher education over the years has evolved to incorporate three attributes commonly reffered to as openness, massiveness and ubiquitousness [1]. These attributes have been predominantly evident in courses called Massive Open Online Courses (MOOCs) [1]. The 
possibility of creating and sharing knowledge increases every day, and to attract new audiences, the educational agents have been diversifying their offer, offering courses in the distance modality and combining virtual learning with the in-person regime, resorting to Online open and Massive courses, especially the English Massive Open Online Course (MOOC). MOOCs have three important attributes, they are "massive", in terms of student capacity, they are "open" meaning that anyone can enrol and information is not ristricted and lastly they are "online courses" available to anyone with internet access [3].

This trend has brought new challenges and the need to differentiate the identity of the Open University (UAb). We are witnessing a competition between conventional higher educational institutions (HEI), which misconstrues the concept of open learning, online, and distance learning, thus distorting their application. The target audience of these courses are specific, well structured, and generally, seek a certified higher education as a solution to their professional and personal goals. However, the commercialization of education is proliferous, and the threats to accessibility and fairness are felt globally. This expansion needs a large contribution to the distance and open education modalities. In this global higher education challenge, open universities can be the nuclear vehicle of expansion, especially in the face of the sustainability challenges defined by the United Nations. An advantage of distance education is that it is customised for students. This notion is supported by [4] who suggested that students are at the center of the distance education eco-system and are key in driving the process.

Open universities have made lifelong learning respectable for the first time in higher education, changing the mindset about opportunities for access to higher education. Open universities have also innovated through the use of technologies, first with the means of classical broadcasting as Radio Television, and for 30 years with the challenges and opportunities of the digital revolution. Another important aspect of the pioneering of open universities was the innovation of educational logistics, with the offer of pedagogical services in scale, with efficiency and quality. The educational logistics was, in fact, a discipline created by open universities. The scale was another important feature of the open universities. Its goal of providing educational opportunities to as many students as possible implies growth and continuous expansion of services and capacities. This attitude contributed to modifying the mentality of higher education.

The work is thus structured: first, we will discuss the digital revolution and the trajectories of open universities, and address the emerging technologies in distance education. In point three we will make a brief presentation of the new pedagogical generation of digital education. In point four, the threats of the digital revolution for open education will be addressed, and in point five, we will point out the challenges, opportunities, and strategies to achieve the success of the expansion and accessibility of higher education that guide the mission of Open universities. 


\section{$2 \quad$ Literature Review}

\subsection{The digital revolution and the trajectories of open universities}

The digital revolution, along with vast structural changes in higher education, led to the erosion of the advantages of pioneering and leadership that open universities enjoyed in distance learning during their first 25 years of existence [5]. The threats and challenges created by the current scenario demonstrate several weaknesses inherent in the institutional consolidation of partially stalled and complacent models. These threats put not only in question the ability of open universities to contribute to the UN's sustainability goals, but also in some cases their own survival. To face these challenges requires profound transformations that cultivate a culture of deep incorporation of innovation and leadership. The question is: the institutional model that has been innovative and has been in action for 50 years, is it suitable for the future? The Open University (OU) of the United Kingdom, the mother of all open universities, marks 50 years of existence in 2019. Although there are reasons for celebration, there are also reasons for concern [6]. The number of students has declined, about $33 \%$ since 2010. This reduction causes severe stress in the institution, with loss of human and economic resources, and puts it in an unsustainable situation. The number of students currently stabilized, but the target audience over the 50 years who sought in the UK or personal development opportunities, has disappeared, and this has ceased to fulfill its lifelong learning role. In Europe, this model also undergoes governmental scrutiny. Four of the European open universities are under threat of closure.

However, it is not all bad news because two of the European open universities are experiencing vigorous growth. The panorama is mixed and it is necessary to reflect on this model in a skeptical and inquisitor way. What is still valid in this model, in view of the changes recorded in the current teaching environment? Is it a suitable model for the next period? To answer these questions, more research is needed on EaD policies and Strategies [6]. In this path, it is necessary to rethink the concept of open education, which has several constituent elements in rapid development, such as open educational resources (REA), open educational Practices (EAP), the Massive Open Online Course (MOOC), and Incorporation of non-formal qualifications in the HEI (higher education institutions). It is also necessary to analyze the emerging trends of informal learning at the margins of the institutions and incorporate them into innovative, collaborative and more student-centered curricula, then redesign the structures of the degree conferring courses, whose little flexibility and duration marginalize a large part of lifelong learning.

Having as its starting point the philosophy and modus operandi expressed in the missions of open universities, several threats and weaknesses of the current models are identified, but there are also great valences and virtues that can be constituted in forces of equity and accessibility in the massification of higher education. The UAb Virtual pedagogical model is based on four pillars: student-centered learning; flexibility, interaction, and digital inclusion [7]. The Virtual pedagogical model of UAb [7], goes against the model that [8] initially proposed. The model assumes that learning occurs in the community, through the interaction of the three interconnected nuclear 
components, and is based on the constructivist paradigm. The Constructivist principles advocate the focus on the student and the belief that all information and learning are conceptualized through experiences and interactions in the Virtual Learning Environment (AVA) because the social context substantially affects the nature of pedagogical activities and their results. One of the main concerns of Constructivism is the way the student interacts with his/her environment. In the research community $(\mathrm{CdI})$, the community is represented by students and teachers participating in the AVA.

The investigation represents the process through which students obtain new knowledge and understanding of the curriculum. To acquire this new knowledge, the elements of the community have to act and interact through their social, cognitive and teaching presences. This model emerged and was made possible by the technologies that emerged with the digital revolution. In the present, characterized by many as the entry of the post-digital era, there are some pillars that remain as conductive wires of coherence since the beginning of the open distance education. However, there are also several salient trends that will shape the future of the sector, several of them already with translation and applicability in existing pedagogies and technologies. The master lines transversal to the accelerated change of the current paradigm meet in the concepts of openness, diversity, flexibility, personalization, quality, and authentication and will inevitably have to sustain itself in the pillars of research and innovation, pedagogical and technological.

The technologies used for learning are increasingly cheap and distributed and are progressively more controlled by students [9]. The evolution of e-learning since the definition of the Edinburgh sceneries [10], shows that there will not be a single uniform future for this field. Distinguished in four categories, these scenarios were designed to be neutral in relation to digital technologies employed and, after 15 years, its predictive character and accuracy are reaffirmed. The scenarios referred to are as follows:

- Virtually Vanilla - eLearning Technologies controlled by large companies and institutions;

- Back to the future - a return to traditional values and classroom education, promoted by the loss of confidence in eLearning;

- Web of confidence - the Web offers people new forms of collaborative learning and work, leading to decentralization and a shift of power out of large organizations;

- U Choose - A world where people are frustrated by new technologies and reject them but find new ways to regain control of their learning and increase their independence from central authorities.

As the study of the generations of EaD also demonstrates, the emergence of a new pedagogical generation does not cause the extinction of the former; On the contrary, they coexist, expanding through the new possibilities conferred by technology [11]. The technologies evolve through a process of construction and recombination. Each innovation is supported in the previous and in turn, opens new possibilities for innovation, as well as constraints, limitations, and threats. It is therefore expected that all Edinburgh scenarios persist and originate new forms of digital learning, some of them 
already in the process of current creation and growth. No scenario will dominate the others, for they will all find their niches. The borders are also struggling because although the institutions maintain the tendency to centralize in Learning Management Systems (LMS), both students and teachers use increasingly personal learning networks supported by social networks, informal and formal learning platforms. Diversity will be the most salient feature of the future of Pedagogies and the organization of EaD.

On the other hand, the replication of the forms of teacher control of the pedagogical models in the eLearning, through the LMS platforms and evaluation activities, undergo challenges of conception and design of practices that allow to regain the motivation lost by the perception of lack of control of the process and alienation of the interest of the participants. Several experiments carried out, for example in MOOCs, reveal the inherent weakness of the tendency. Even with mature, competent and skilled students, when they withdraw control, certification, and accreditation of online courses based on classroom pedagogies, they demonstrate their lack of evident value in the low rates of success and Completion of the participants.

\subsection{Emerging technologies in distance education}

EaD can (and must) be a choreographed dance and carefully orchestrated between technology and pedagogy [12]. The emergence of information and communication technology have created a revolutionary disruption [13]. In terms of technology, several initiatives are identified that will open up great possibilities for the future. The "Next Generation Digital Learning Environment" by Educause [14] and the "Learning and Performance Support System" in development by the National Research Council of Canada [15], are very real examples of tendency to focus on individualization and customization of highly sustained learning in the network. This trend aligns with the growing and long-announced relevance [16] of the realization of personal learning environments or personal learning atmospheres (PLEs). Many technological advances will enable this pedagogical innovation, highlighting the following [9]:

- Analysis of learning data and information flows through adaptive and customizable hypermedia

- Collective Technologies (collaborative filters, labels and labels semi and customized, reputation systems, research algorithms, and network mining, etc.) that enable the communication of many to one.

- Deep learning and artificial intelligence will enable intelligent mentoring systems and already offer contextual help and automatic translation

- Disaggregated, compatible and interoperable tools and services will overcome monolithic LMS and facilitate the collection and aggregation of digital evidence of learning activities to enable the emergence of competence accreditation systems distributed in networks

- Mobility and diversity of devices, which will enable the paradigm shift to learning embodied in the daily reality and independent of time and space 
- Internet of things and ubiquitary computation will allow a growing interaction between people and objects

- Virtual and augmented reality and 3D printing will increasingly merge the real with the virtual, creating learning scenarios of high authenticity and increasingly imbuing teaching with genuine experiences, engaging and inspiring.'

Data analysis, collective technologies and artificial intelligence will facilitate the delegation of many teaching processes to computational agents, making it possible to scale and massify the educational offer without compromise of quality. The breakdown goes against two overlapping tendencies, of easing and increased control of the educational process to the student [9]. This opening will broaden the educational offerings beyond the traditional institutional boundaries and will allow the customization of learning environments. The mobility and diversity of devices with immersion and overlapping of the Web in physical reality are supported by the aforementioned trends, but further expand the possibilities of eLearning leaving the classrooms, freeing it from computers Personal and secretaries. These technologies will ultimately allow you to incorporate eLearning in the real world, in the everyday flow of all people, anywhere and at any time. This tendency represents the extinction of several aspects of the control of learning by the traditional teacher, demanding the creation of pedagogies that recognize the new paradigm of profound incorporation, without separation between life and education.

\subsection{The new pedagogical generation of digital education}

In this technological context, [17] have nicknamed the new pedagogical generation of "holistic generation", not only by the integration of previous pedagogical generations but also by the profound integration of pedagogy in all aspects of the students' lives. This new generation of pedagogies, teaching and learning methods will undoubtedly focus predominantly on the student's individuality, and social networks will be the central means of the personalization process. The integration of social networks into institutional structures of education will enable the creation of individualized and highly adaptable academic pathways to the needs of each student. By maintaining the clear structure of the learning objectives provided by the institutional curricula and supervision while combining it with new ways of sharing the control of the educational process and of learning experiences, it will be possible to increase the quality and efficiency of education and at the same time positively influence students' motivation.

This transition requires great effort in research and development for the design of pedagogical methods. Learners require guidence along the educational process [18]. As data analysis becomes an increasingly powerful tool in teaching, the creation of pedagogical methods will often emerge from the data collected, not only from drawings supported by theories defined as a priority. It is highly possible that the new generation of pedagogies is discovered rather than invented [9]. However, the transition also requires research and policy development for the creation of educational informatics tools that aggregate the learning activities distributed in the network and 
validate the certification of education combined with the closed institutional frameworks. The breakdown will lead to a redefinition of the teacher's role, since it loses some control, becoming a service provider. Depending on the context and phase of the teaching process, the teacher may have valences from the direct orchestration, but his model, guide and learning support functions will gain relief. The breakdown will also create challenges related to the granularity and accreditation of the courses, as the organizational structure of the institutions becomes flexible to allow the customized academic pathways.

\subsection{Digital revolution threats to open education}

As major technological opportunities arise for the expansion and fairness of education in an opening model, the threats that expose the weaknesses of the open universities model are also growing, as is summarised in table 1. Open universities are faced with a paradox between the mercantilism of private education, the pressures of surveillance capitalism on the one hand, and the effort to increase the openness of public science and education by another [19]; [9]. This fight will continue among agents seeking profit in digital education at any cost, and the people and institutions that consider knowledge as a social good gains value as it is distributed in an open way. The spirit of innovation that defined the genesis of open universities is losing itself over time, as institutions grow and settle. The erosion of the advantage of the first move is happening, in the face of the digital change [6]. Most traditional universities already accept a combination of the in-person model with independent study formats based on e-learning and offer blended programs. The private sector has also not adhered to these modalities. They have been applied irresponsibly by people without skills in EaD and there have been several cases of misapplication and malpractice of these modalities, which has stripped them of credibility in the eyes of society. The challenge of Open Universities is in the maintenance of their identity as innovators of higher education. The generalization of MOOCs by default of open universities is emblematic and poses a major threat. There are many criticisms of the MOOCs, but they have stirred the world in an undeniable and inescapable way. It was not the intention of open universities to originate this phenomenon, but there was a reaction of wounded pride because they had felt outdated in their mission to innovate and invent new ways of educating. After the initial period, open universities accepted and even somewhat embraced the MOOCs, having corrected some flaws and adjusted the trajectory with qualitative improvements.

\section{Research Methodology}

The research adopted a quantitative systematic review of literature on open education. Data was collected from articles published from 2000 to 2019 hosted in popular academic databases that include Scopus and the International Bibliography of the Social Science (IBSS). Unique keywords namely "Massive Online Open Courses", "Open Universities" and "Higher Education" were used to screen for relevant results 
(articles) for review. Relevant information was extracted from abstracts/ full papers. The majority of research used was obtained from the following journals: International Journal of Interactive Mobile Technologies, European Journal of Open, Distance and E-learning, International Journal of Educational Technology in Higher Education, Italian Journal of Educational Technology, eLearning Papers and International Journal of Emerging Technologies In Learning. A key inclusion criteria for the systmatically selected papers was to include particially or wholly the idea of open/ online education or technology in education in line the the study's objective.

\subsection{Document exploitation}

In addition to the aforementioned sources of information that where utilized. The researchers conducted document exploitation. As put forward by [20], literature from documented material should be viewed equally the same as field notes. The same point was buttressed by [21], [22] who referred to documented literature as "everything is data" and [23] who asserted that a "cache of archival material" is equivalent to a collection of interviews and field notes. In this study the researchers reviewed documents with literature on open university policies, Teaching and Learning model for open universities, open university transformational documents, information posted on open universities official websites. These documents served two purposes. Firstly, they were treated as another source of data collection. Secondly, as noted by [24], prior reading provided models to help the researchers make sense of the data gathered on open universities. The following section provides the discussion for the present research.

\section{Discussion}

\subsection{Challenges, opportunities, and strategies for the future}

The digital revolution has brought changes to all fields, including education. It is currently ubiquitary, as is evident by the presence of LMSs in all universities. So what differentiates open universities? How do you keep them in the leadership of education? Open universities need to reformulate their innovation policies and strategies so that they can remain active and relevant in their mission to educate the world fairly and affordably. It is necessary to rethink innovation. Open universities should be institutions of embedded innovation [6], where constant and continuous innovation is incorporated into the culture of management, strategic planning, and educational practices. At first, open universities understood that traditional teaching and learning models were inadequate for their mission, and innovated, both in the technologies employed and in the construction and development of pedagogical theories and practices. However, in the face of threats, it is necessary to reinvent open universities. They cannot remain in the model for 30 years, and for this change, it is necessary to put innovation at the heart of its institutional culture. The challenge of open universities is to ensure that they cease to be complacent and regain the status of the most 
innovative institutions in the way of combining technologies to find new solutions. It is necessary to develop leadership at all levels, and at the international level, it is necessary to cultivate the distributed leadership [5]. It is also necessary to develop the vocational training of teachers. More attention is needed to the surrounding environment, for early detection of changes and strategic planning. It is necessary to define development and quality of new forms and dominate the quality agenda of higher education, since quality has been defined based on simplistic, antiquated, incomplete and asymmetric criteria that do not emphasize the important role and the capacities of open universities, which have the quality referential aimed at inclusion, lifelong learning, and sustainability.

It is necessary to develop the potential of ICT and incorporate them at all levels of the institution. One of the ways to innovate at this level that is already underway in open universities is to create more evolved personal learning environments, which integrate traditional LMS with social networks. Social networks are a source of enormous innovation. Recent research results on its use in the field of education are encouraging [25]. In the last 15 years, several professors and several institutions have used social networks to amplify their LMSs in the learning process, and it is possible to identify several benefits: timely notifications, increase in social presence, increased academic integration in the real world, network effects and background conversations, increased persistence, satisfaction, and learning perception. The use of social networks has the potential to achieve the goal of integrating the school into the real life of students and teachers, which extends naturally to the surrounding societies and aligns with the philosophy and mission of open universities. In the current panorama of accelerated but often unstructured incorporation of new technologies in education, open universities also have the opportunity to remain in the leadership of innovation and research for the development of pedagogies, practices, and policies that sustain and guide social learning [19].

In view of the investment capacity of large companies, which can easily take advantage of the commercial cloud and big data services, coupled with the most aggressive copyright protection tools, open universities need to be innovative in the way they are positioned in society and how they relate to other higher education institutions. The breakdown and the granular autonomy of online education systems can be effective strategies to reduce costs while maintaining the quality of education [26], [27]. With the new support policy infrastructure defined from the Open Edu project, open Education in the HEI is conceived in ten dimensions, including the resources and the repositories of free access in a broader concept of modernization of education boosted by digital technologies [28]. The goal is to remove barriers, promote transparency for the sharing of practices that allow broadening access and participation to all, making learning accessible, abundant and customizable. In this context of increased openness, implementation of shared practices and collaborative, networked work organization, open universities have the opportunity to play a driving force of change - thanks to their profound technical knowledge, human potential, and culture of open practices. This role can be played in various ways, namely as leaders in the adoption of practices, definition of policies, and in the training and education of scientific agents [29]. However, in order to take advantage of these opportunities, universi- 
ties dedicated to distance education need to transform and adopt a new organizational approach, such as structured learning organizations in open networks [27].

In the context of competition for students' attention, the most dynamic educational resources, which could be modified, adapted and shared freely, have a great advantage over the closed resources. However, these practices have insufficient adoption, and there is still a widespread lack of knowledge of these concepts in the [27]. Open universities, such as policy leaders, PEA and REA, have a broad competitive advantage, especially at this moment of convergence of open education and open science movements, to serve as references to the principles of transparency, collaboration, and openness of knowledge. Open universities have to face this tremendous opportunity as one of their priorities, considering that the REA is pedagogies and disruptive technologies [26] that align directly with the mission of fairness and accessibility in education.

Table 1. SWOT Analysis for Open Universities.

\begin{tabular}{|c|c|}
\hline $\begin{array}{l}\text { Forces } \\
\text { - Dedication to openness, flexibility, and } \\
\text { accessibility } \\
\text { - Gender equality in recruitment } \\
\text { - Dedication to technology-boosted learning } \\
\text { (TEL). }\end{array}$ & $\begin{array}{l}\text { Opportunities } \\
\text { - Alignment of the UN's sustainable development } \\
\text { goals to } 2030 \text { with the global expansion of higher } \\
\text { education } \\
\text { - Restoration and redefinition of the quality } \\
\text { concept in the systems of higher education in mass } \\
\text { - Lead the development of study plans for } \\
\text { sustainability. }\end{array}$ \\
\hline $\begin{array}{l}\text { Weaknesses } \\
\text { - Completion and graduation rates } \\
\text { - Reputation and brand } \\
\text { - A slowdown in innovation capacity by the } \\
\text { resistance of human frames to change. }\end{array}$ & $\begin{array}{l}\text { Threats } \\
\text { - Governmental disinterest by the models of open } \\
\text { universities } \\
\text { The interest of other universities in digital learning } \\
\text { (e.g.: MOOCs) } \\
\text { New mixed and part-time teaching offerings from } \\
\text { established universities } \\
\text { New online universitiesOpening of markets to } \\
\text { foreign agents of higher education. }\end{array}$ \\
\hline
\end{tabular}

Source: [6]

This study's implications are centered around three themes: theoretical implications, practical implications and policy implications.

\subsection{Theoretical implications}

The current study attempted to undertake a research in an often most neglected context of open universities and (MOOCs) but yet an important sector of the higher institutions of learning around the world. Hence, the present investigation offers suggestions for academics, as it makes a significant contribution to the open learning and technology enhanced learning literature by systematically exploring the threats, challenges, and opportunities for open universities and massive online open courses in the digital revolution. 


\subsection{Practical implications}

On the practitioners' side, this investigation presents ways in which open university managers can improve their institutions. Given the threat of other universities in digital learning (e.g.: MOOCs); administrators of open universities could focus on corporate entrepreneurship with innovation in mind, which will eventually enhance the business performance of open universities. [30] elucidates that corporate entrepreneurship is the process when a person or a team develops a new business unit within an existing business through identification of a new opportunity or business idea. Therefore an organization like an open university can venture into corporate entrepreneurship where it can engage itself in an entrepreneurial activity within its existing business which is providing education. It means of administrators of open universities can have a competitive edge over newly established open university, as they will be having a variable of offers, in terms of their services. Other implications are that management of open Universities will learn and change for the better in the way they are doing their things and focus more on corporate entrepreneurship as it brings more money to the institution, student learning and research.

\subsection{Policy implications}

This study offers suggestions for strategists who seek improve the offering of massive online open courses and the performance of open universities. It is therefore imperative to offer a competitive quality of education from the students' perspective [31]. In addition, the implementation of technology in education provides potential for success [32]. The outcomes obtained from this research can be utilized to produce new policies or revise existing policies. For example, this study has confirmed that there is an opportunity for restoration and redefinition of the quality concept in the systems of higher education in mass. This will definitely enhance the crafting of new policies pertaining to the quality concept in the systems of higher education.

\section{$5 \quad$ Limitations and Future Research Opportunities}

Despite the germane insights offered by this study, this study had limitations which are expected to lead to future research. Although this study fills a gap in the academia, by highlighting the threats, weakness, opportunities and forces. It should be noted that this study only focused on a systematic review of literature. Hence to obtain other insightful results, precisely more illuminating and more extravagant information, future examinations ought to conduct interviews with leaders of Open Universities and instructors of Massive Online Open Courses. Nevertheless, the results discovered in this study may help to decide on future directions. For instance, institutions of higher education can take to make optimal use of Massive Online Open Courses, and at the same time avoiding the threats as much as possible. There is also an opportunity for open education where less traditional lecturing and more facilitative and guided 
approaches to education can find a place in this new landscape of online learning where increased fees for established models may act as a deterrent to students.

\section{Conclusion}

Through the critical evaluation of these institutions in the global educational panorama, we identify the need for profound and imminent transformations. These transformations open up several paths of challenges and opportunities for the strengthening of open education. Through a huge effort of change, it will be possible to maintain the inescapable role of these institutions in promoting the growth and sustainability of higher education. At the time when a decisive law project is being discussed to redefine the role of the Open University of Portugal, it must actively pursue the goal of maintaining itself as a leader in innovation and quality, so that it can continue to define the future of distance education and digital learning.

\section{$7 \quad$ References}

[1] Atenas, J. (2015). Model for democratisation of the contents hosted in MOOCs. International Journal of Educational Technology in Higher Education, 12(1), 314.

[2] Tait, A. (2008). What are open universities for?. Open Learning: The Journal of Open, Distance and e-Learning, 23(2), 85-93. https://doi.org/10.1080/02680510802051871

[3] Adham, R. S., \& Lundqvist, K. O. (2015). MOOCs as a method of distance education in the Arab world-A review paper. European Journal of Open, Distance and Elearning, 18(1), 123-138. https://doi.org/10.1515/eurodl-2015-0009

[4] Lestari, I., Maksum, A., \& Kustandi, C. (2019). Mobile Learning Design Models for State University of Jakarta, Indonesia. International Journal of Interactive Mobile Technologies (iJIM), 13(09), 152-171. https://doi.org/10.3991/ijim.v13i09.10987

[5] Tait, A. (2018). Open Universities: the next phase. Asian Association of Open Universities Journal 13(1), pp.13-23. Disponível em https://doi.org/10.1108/AAOUJ-12-2017-0040

[6] Tait, A. (2019). Open Universities: A Technology For The 21st Century? Comunicação apresentada na $1 .^{\text {a }}$ Conferência Internacional de Investigação em Educação Aberta, a Distância e em Rede, 27 Fevereiro, Lisboa.

[7] Pereira, A., Mendes, A. Q., Morgado, L., Amante, L., \& Bidarra, J. (2007). Modelo pedagógico virtual da Universidade Aberta: para uma universidade do futuro. 1-112.

[8] Garrison, D. R., Anderson, T., \& Archer, W. (2000). Critical inquiry in a text-based environment: Computer conferencing in higher education model. The Internet and Higher Education, 2(2-3), 87-105. https://doi.org/10.1016/s1096-7516(00)00016-6

[9] Dron, J. \& Anderson, T. (2016) The Future of E-learning. In Haythornthwaite, C.; Andrews, R.; Fransman, J. \& Meyers, E. (Eds.), The SAGE Handbook of E-learning Research Second Edition. Sage. https://doi.org/10.4135/9781473955011.n1

[10] Bell, M.; Martin, G. \& Clarke, T. (2004). Engaging in the future of e-learning: a scenariobased approach. Education + Training 46(6/7), pp.296-307. https://doi.org/10.1108/0040 $\underline{0910410555204}$ 
[11] Anderson, T., \& Dron, J. (2011). Three generations of distance education pedagogy. The International Review of Research in Open and Distributed Learning, 12(3), 80-97. https:// doi.org/10.19173/irrodl.v12i3.890

[12] Anderson, T. (2009). The dance of technology and pedagogy in self-paced distance education. Comunicação apresentada no $17^{\circ}$ ICDE World Congress, Maastricht.

[13] Suartama, I. K., Setyosari, P., Sulthoni, S., \& Ulfa, S. (2019). Development of an Instructional Design Model for Mobile Blended Learning in Higher Education. International Journal of Emerging Technologies in Learning (iJET), 14(16), 4-22. https://doi.org/10.39 91/ijet.v14i16.10633

[14] Brown, M.; Dehoney, J. \& Millichap, N. (2015). The Next Generation Digital Learning Environment - A Report on Research. EDUCAUSE Learning Initiative, EDUCAUSE.

[15] Fournier, H. \& Molyneaux, H. (2015). Learning and performance support systems: personal learning record. Information and Communication Technologies User Studies White Paper. National Research Council of Canada.

[16] Attwell, G. (2007). Personal learning environments: The future of eLearning? eLearning Papers, 2(1), 1-7.

[17] Anderson, T., \& Dron, J. (2014). Teaching Crowds: Learning and Social Media. Edmonton, Canadá: Athabasca University Press.

[18] Neumann, S., Klebl, M., Griffiths, D., Hernández-Leo, D., de la Fuente Valentín, L., Hummel, H., \& Oberhuemer, P. (2010). Report of the results of an IMS learning design expert workshop. International Journal of Emerging Technologies In Learning (IJET), 5(1), 58-72. https://doi.org/10.3991/ijet.v5i1.1045p

[19] Anderson, T. (2019). Social Media and Scholarly Research. Comunicação apresentada na 1. ${ }^{a}$ Conferência Internacional de Investigação em Educação Aberta, a Distância e em Rede, 27 Fevereiro, Lisboa.

[20] Turner, B. (1983). The Use of Grounded Theory for the Qualitative Analysis of Organisational Behaviour. Journal of Management Studies, 20(2), 333-348.

[21] Glaser, B. (1992). Basics of Grounded Theory Analysis. Califonia, Sociology Press, Mill Valley.

[22] Glaser, B. (1998). Doing Grounded Theory: Issues and Discussions. Califonia, Sociology Press, Mill Valley.

[23] Strauss, A. L., \& Corbin, J. (1990). Basics of Qualitative Research: Grounded Theory Procedures and Techniques. Newbury Park, CA: Sage.

[24] Goldkuhl, G., \& Cronholm, S. (2003, March). Multi-grounded theory-Adding theoretical grounding to grounded theory. In 2nd European Conference on Research Methodology for Business and Management Studies, Reading University, Reading, UK (pp. 88-111). https:// doi.org/10.1177/160940691000900205

[25] Anderson, T., \& Dron, J. (2017). Integrating learning management and social networking systems. Italian Journal of Educational Technology, 25(3), 5-19.

[26] Anderson, T., \& McGreal, R. (2012). Disruptive Pedagogies and Technologies in Universities. Educational Technology \& Society, 15(4), 380-389.

[27] Teixeira, A., Bates, T., \& Mota, J. (2019). What future(s) for distance education universities? Towards an open network-based approach. RIED. Revista Iberoamericana de Educación a Distancia, 22(1),107-126. https://doi.org/10.5944/ried.22.1.22288

[28] Santos, A.; Punie, Y. \& Muñoz, J. (2016). Opening up Education - A Support Framework for Higher Education Institutions. European Commission Joint Research Centre Science for Policy Report. Bruxelas.

[29] Pontika, N.; Knoth, P.; Cancellieri, M. \& Pearce, S. (2015). Fostering Open Science to Research using a Taxonomy and an eLearning Portal. Em: iKnow: 15th International Confer- 
ence on Knowledge Technologies and Data-Driven Business. https://doi.org/10.11 45/2809563.2809571

[30] Chinomona, E., Maziriri, E., \& Moloi, K. C. (2014). Corporate entrepreneurship with innovation in mind in one university of technology in South Africa. Mediterranean Journal of social sciences, 5(23), 20-29. https://doi.org/10.5901/mjss.2014.v5n23p20

[31] Matlakala, M., Chiliya, N., Chuchu, T., \& Ndoro, T. (2019). An Empirical Study on the Predictors of the Perceived Quality of Learning at Institutions of Higher Education: 2D Model Approach. International Journal of Emerging Technologies in Learning (iJET), 14(15), 67-77. https://doi.org/10.3991/ijet.v14i15.10608

[32] Chuchu, T., \& Ndoro, T. (2019). An examination of the determinants of the adoption of mobile applications as learning tools for higher education students. International Journal of Interactive Mobile Technologies (iJIM), 13(3), 53-67. https://doi.org/10.3991/ijim.v13i03. $\underline{10195}$

\section{Authors}

Prof Maria Nascimento Cunha Ph.D. is a Professor at the Universidade de Aveiro. She holds a Ph.D. in Marketing and a Post-PhD in Consumer Behaviour. She has also held several management roles at Nike and Escada Group. She currently teaches and researches in Educational Technology.

Dr Tinashe Chuchu Ph.D. is a Senior Lecturer in the Department of Marketing Management at the University of Pretoria, South Africa. He's research area of focus is Customer Decision-making, Consumer Behaviour and Marketing Management. He has also conducted research in Technology adoption in education.

Dr Eugine Tafadzwa Maziriri Ph.D. is a Senior Lecturer in the Department of Business Management at the University of the Free State, South Africa. He has a keen interest in Consumer Behaviour and Business Management. Moreover, he has published in numerous papers in peer-reviewed international and local accredited journals.

Article submitted 2020-01-26. Resubmitted 2020-03-19. Final acceptance 2020-03-22. Final version published as submitted by the authors. 